\title{
Nitrogen in Soil in Response to Cover Plants and Irrigation Levels in Semi-Arid
}

Tiago da Costa Silva Barbosa ${ }^{1 *}$, Gomes Costa MC $^{2}$, Feitosa Lacerda $\mathrm{C}^{3}$ and Lima Barbosa $\mathrm{FE}^{2}$

${ }^{1}$ Department of Agriculture, Federal Institute of Piauí, Brazil

${ }^{2}$ Department of Soil Sciences, Federal University of Ceará, Brazil

${ }^{3}$ Department of Agricultural Engineering, Federal University of Ceará, Brazil

\section{Research article}

Volume 4 Issue 3

Received Date: March 09, 2020

Published Date: April 06, 2020

DOI: $10.23880 /$ jenr- 16000195

*Corresponding author: Tiago da Costa Silva Barbosa, Federal Institute of Piauí, Campo

Maior, Piauí, Tel: +55 (89) 9 99775921, Brazil; Email: tiago.silva@ifpi.edu.br

\section{Abstract}

The use of different species of cover plants and irrigation levels can affect the availability of nitrogen $(\mathrm{N})$ and forms of $\mathrm{N}$ in the soil. In this study, total $\mathrm{N}$ and its inorganic forms in the soil were evaluated in the experiment with banana cultivation associated with cover plants and irrigation levels. The experiment was conducted in the state of Ceará in the Brazilian semiarid region with the design of randomized blocks and split plot with four replications. In the plots were evaluated four irrigation levels $(50,75,100$ and $125 \%$ of evapotranspiration of banana plants), were evaluated in the subplots four cover plants (Pueraria phaseoloides Benth, Calopogonium muconoides Desv., spontaneous vegetation and residue of banana plants) and sub-subplots two soil layers $(0-5 \mathrm{~cm}$ and 5-10 cm) were evaluated. In general, the result of the leguminous Pueraria phaseloides Benth showed a higher content of total $\mathrm{N}$ and its inorganic forms throughout the evaluation period in comparison to the other types of coverage. As for the effects of irrigation levels, it was found that the highest levels led to the lowest content of nitrate (N$\mathrm{NO}_{3}^{-}$), compared to the levels of ammonium $\left({\mathrm{N}-\mathrm{NH}_{4}+}^{+}\right.$). Regarding the depth, was observed higher levels of total $\mathrm{N}$ and $\mathrm{N}-\mathrm{NO}_{3}^{-}$ in the most superficial layer and higher $\mathrm{NH}_{4}+$ levels in the subsurface layer of the soil. Thus, the use of Pueraria phaseoloides Benth as a cover plant can improve the availability of $\mathrm{N}$ for a crop of agronomic interest, mainly in the most superficial layer of soil, with most of this $\mathrm{N}$ being in the form of $\mathrm{NO}_{3}$ :

Keywords: Nutrient Cycling; Soil Protection; Plant Residues; Vegetable Biomass

\section{Introduction}

Nitrogen $(\mathrm{N})$ is an essential chemical element for plant growth [1]. The most used soil management technique to increase $\mathrm{N}$ content is the mineral fertilization FAO [2] that can increases crop yields as well as crop profitability. However, mineral fertilizers can increase production costs Mahanta, et al. [3] and may represent an environmental risk in soils of tropical regions. Part of the nitrogen fertilizers applied in the soil is lost. The lost $\mathrm{N}$ has high pollutant potential and, once carried to ground waters, it may cause contamination of aquifers, rivers and lakes [4].
Markets and social movements claiming for agricultural sustainability have encouraged green manure as an alternative to nitrogen mineral fertilization, aiming the conservation of natural resources, the maintenance of soil quality in the agricultural systems and the reduction of production costs Lechenet, et al. [5].

Nitrogen input by plant material can reduce the use of mineral fertilizers. The $\mathrm{N}$ content in vegetal tissue is variable between plant species and leguminous usually have more $\mathrm{N}$ due the process of biological fixation of atmospheric $\mathrm{N}$ $[6,7]$. Returning plant residues to the soil is an alternative 


\section{Journal of Ecology and Natural Resources}

and sustainable way of $\mathrm{N}$ fertilization and the main crop will benefit from $\mathrm{N}$ mineralization [8]. However, in tropical regions it also represents a risk of $\mathrm{N}$ losses due to the quick $\mathrm{N}$ mineralization that may not match with the period of high nutrient demand by the main crop, causing $\mathrm{N}$ losses in agroecosystems.

One alternative to use leguminous as $\mathrm{N}$ source is the intercropping between leguminous species and the main crop. This management promotes $\mathrm{N}$ availability for the main crop when it has the condition to absorb the mineralized nutrient after cutting leguminous plants [8].

According to Huygens, et al. [9], inorganic $\mathrm{N}$ can be found

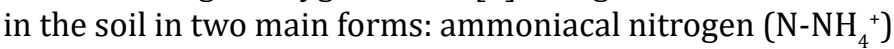
and nitric nitrogen $\left(\mathrm{N}^{-\mathrm{NO}_{3}}{ }_{3}^{-}\right.$). Proportions between inorganic $\mathrm{N}$ forms are influenced by soil management systems Tian [10] because the inorganic $\mathrm{N}$ form available in the soil may indicate aspects related to soil aeration [11].

Among the factors influencing inorganic $\mathrm{N}$ forms proportions there is the irrigation. Once its inadequate use may promote temporary flood, limiting $\mathrm{N}^{-\mathrm{NO}_{3}}{ }_{3}^{-}$availability [12]. In soils without oxygen restrictions $\mathrm{N}^{-} \mathrm{NO}_{3}{ }^{-}$is the predominant $\mathrm{N}$ form [13]. Nitrogen as nitrate is predominant in superficial soil layers where nitrification conditions are better [14]. On the other hand as soil depth increases oxygen content is reduced favouring $\mathrm{N}-\mathrm{NH}_{4}{ }^{+}$form [14]. In irrigated areas the predominance of $\mathrm{N}_{-} \mathrm{NO}_{3}{ }^{-}$in the soil solution may favour $\mathrm{N}$ losses by leaching and/or runoff. This strengthens the need to adopt adequate irrigation levels to avoid not only water losses, but also $\mathrm{N}$ losses.

This study was carried out to prove the following hypotheses: i) the traditional management of banana residues by growers and the presence of cover crop species contribute with $\mathrm{N}$ availability to the main crop; ii) irrigation levels decrease $\mathrm{N}-\mathrm{NO}_{3}{ }^{-}$and increase $\mathrm{N}^{-} \mathrm{NH}_{4}{ }^{+}$forms; and iii) the superficial soil layer has higher $\mathrm{N}$ amount than the deeper one.

\section{Material and Methods}

The study was developed in an experiment with banana trees installed in 2010 and conducted in the Vale do Curu Experimental Farm (Pentecoste, CE - Brazil). According to Köppen's classification system the climate of the region is BSW' $h$ ', which is semiarid with irregular rains, average annual rainfall of $797 \mathrm{~mm}$, concentrated between January and April, and maximum and minimum annual temperature averages of $33.4^{\circ} \mathrm{C}$ and $22.4^{\circ} \mathrm{C}$, respectively [15]. The soil of the experimental area was classified as Neossolo Flúvico [16]. The $\mathrm{N}$ content in the soil before the installation of the experiment was $0,65 \mathrm{~g}_{\mathrm{kg}}{ }^{-1}$.
The experimental design was in randomized blocks and split-splitplot scheme with four replicates. The treatments evaluated in the plots were four irrigation levels corresponding to $50,75,100$ and $125 \%$ of banana plants evapotranspiration. The plots $(12 \times 40 \mathrm{~m})$ were constituted by four rows of banana tree cv. Prata Anã, planted in a simple row system with spacing of $3 \times 2 \mathrm{~m}$, consisting of 80 plants. In the subplots, four cover plants were evaluated: the leguminous Pueraria phaseoloides Benth, the leguminous Calopogonium muconoides Desv., spontaneous vegetation composed mainly by grasses Panicum maximum Jacq, and banana plant residues (conventional management used in this study as a control), totalizing 64 experimental units. Each plot was divided in four subplots $(12 \times 10 \mathrm{~m})$ with twenty plants, the six central plants being considered as useful. The $\mathrm{N}$ contents $\left(\mathrm{g} \mathrm{m}^{-2}\right)$ of cover plants evaluated in this study were 24.2, 12.8, 12.3 and 11.7 for Pueraria phaseoloides Benth, Calopogonium muconoides Desv, spontaneous vegetation and and banana plant residues, respectively. In the sub-subplots two soil layers $(0-5 \mathrm{~cm}$ and $5-10 \mathrm{~cm})$ were evaluated.

Evaluations related to this study were done from July 2012 after the first harvest of bananas and three cuts of cover plants. After cuts, the vegetal residues from cover plants were placed between the banana rows without incorporation.

Soil sampling was done six times based on the cover plant cuts in the same year of evaluation: 1 ) before the cut and deposition, 2) seven days after the cut and deposition, 3) 22 days after the cut and deposition, 4) 37 days after the cut and deposition, 5) 56 days after the cut and deposition, 6) 70 days after the cut and deposition. The soil was sampled in two layers $(0-5 \mathrm{~cm}$ and $5-10 \mathrm{~cm})$, in the banana rows where the plant residues were placed. The soil samples used to determine inorganic $\mathrm{N}$ forms were frozen until the chemical analysis.

The total $\mathrm{N}$ of the soil was determined using the method described in Teixeira [17]. The method is divided in two stages: sulfur digestion and distillation. In the digestion stage, a digestion mixture composed of $\mathrm{Na}_{2} \mathrm{SO}_{4}, \mathrm{CuSO}_{4}$ and $\mathrm{H}_{2} \mathrm{SO}_{4}$ was used in the soil sample, which was then placed in a digester block at a temperature of $350{ }^{\circ} \mathrm{C}$. The distillation stage was made by in the steam distiller. The product of the distillation was titrated with $\mathrm{H}_{2} \mathrm{SO}_{4}$ solution until transformation of coloration blue or green for the pink coloration.

Nitrogen as nitrate $\left(\mathrm{N}-\mathrm{NO}_{3}{ }^{-}\right)$and as ammonium (N$\mathrm{NH}_{4}^{+}$) in the soil were determined according to the method described in Teixeira et al. (2017). The extraction of these mineral $\mathrm{N}$ forms was done using $\mathrm{KCl}\left(1 \mathrm{~mol} \mathrm{~L}^{-1}\right)$ solution. The determination of $\mathrm{N}^{-\mathrm{NO}_{3}}{ }_{3}^{-}$and $\mathrm{N}-\mathrm{NH}_{4}^{+}$was done by means of distillation of the solutions containing these forms of 


\section{Journal of Ecology and Natural Resources}

mineral nitrogen. The product of the distillation was titrated with $\mathrm{H}_{2} \mathrm{SO}_{4}$ until the color change from blue or green to pink coloration.

The variables were statistically analysed using the software ASSISTAT Santos-Silva [18], which allowed the variance analysis by the $\mathrm{F}$ test, and then Tukey test was performed to compare means.

\section{Results and Discussion}

\section{Total nitrogen}

The evaluations to this study were realized after the third cut of the cover plants. The total $\mathrm{N}$ in the soil was altered along the evaluation times which seems to be a consequence of the plant residues placed on the soil. Overall there was an increase in the availability of $\mathrm{N}$ along the time for all treatments, therefore, the cover plants proved to be efficient for this. Cover plants increase total nitrogen in soil Ramos [19], mainly through decomposition of plant residues. In time 1, before the deposition the cover plants, total $\mathrm{N}$ in soil was remaining of the previous cut and the inputs.

Total $\mathrm{N}$ content in response to the interaction between irrigation levels and cover plants is presented in Table 1. In the evaluation times 1, 2, 3 and 6, significant effects of this interaction were observed.

\begin{tabular}{|c|c|c|c|c|c|c|}
\hline \multirow{2}{*}{ Time } & \multirow{2}{*}{ Irrigation Level } & \multicolumn{4}{|c|}{ Cover Plant } & \multirow[b]{2}{*}{ F value } \\
\hline & & $\mathbf{P P}$ & CM & VS & BR & \\
\hline & & \multicolumn{4}{|c|}{ 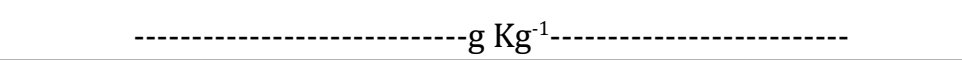 } & \\
\hline \multirow{4}{*}{1} & 1 & $1.31 \mathrm{aA}$ & $0.81 \mathrm{aC}$ & $1.13 \mathrm{aB}$ & $0.74 \mathrm{aC}$ & \multirow{4}{*}{$0.2374^{*}$} \\
\hline & 2 & $1.34 \mathrm{aA}$ & $0.80 \mathrm{aC}$ & $1.08 \mathrm{aB}$ & $0.70 \mathrm{aC}$ & \\
\hline & 3 & $1.33 \mathrm{aA}$ & $0.78 \mathrm{aC}$ & $1.10 \mathrm{aB}$ & $0.69 \mathrm{aC}$ & \\
\hline & 4 & $1.31 \mathrm{aA}$ & $0.74 \mathrm{aC}$ & $1.08 \mathrm{aB}$ & $0.71 \mathrm{aC}$ & \\
\hline \multirow{4}{*}{2} & 1 & $2.11 \mathrm{bA}$ & $1.16 \mathrm{aB}$ & $1.14 \mathrm{aB}$ & $1.16 \mathrm{aB}$ & \multirow{4}{*}{$5.1692^{* *}$} \\
\hline & 2 & $2.36 \mathrm{aA}$ & $1.13 \mathrm{aB}$ & $1.10 \mathrm{aB}$ & $1.01 \mathrm{bB}$ & \\
\hline & 3 & $2.33 \mathrm{aA}$ & $1.10 \mathrm{aB}$ & $1.08 \mathrm{aB}$ & $0.99 \mathrm{bB}$ & \\
\hline & 4 & $2.31 \mathrm{aA}$ & $1.15 \mathrm{aB}$ & $1.06 \mathrm{aB}$ & $0.91 \mathrm{bC}$ & \\
\hline \multirow{4}{*}{3} & 1 & $3.19 \mathrm{aA}$ & $2.20 \mathrm{aB}$ & $2.20 \mathrm{aB}$ & $1.91 \mathrm{aC}$ & \multirow{4}{*}{$4.2402^{* *}$} \\
\hline & 2 & $3.00 \mathrm{abA}$ & $2.25 \mathrm{aB}$ & $2.29 \mathrm{aB}$ & $1.89 \mathrm{aC}$ & \\
\hline & 3 & $2.88 \mathrm{bA}$ & $2.29 \mathrm{aB}$ & $2.39 \mathrm{aB}$ & $1.99 \mathrm{aC}$ & \\
\hline & 4 & $2.93 \mathrm{bA}$ & $2.13 \mathrm{aB}$ & $2.23 \mathrm{aB}$ & $1.88 \mathrm{aC}$ & \\
\hline \multirow{4}{*}{6} & 1 & $4.35 \mathrm{aA}$ & $2.35 \mathrm{aC}$ & $2.75 \mathrm{aB}$ & $2.84 \mathrm{aB}$ & \multirow{4}{*}{$2.6568^{*}$} \\
\hline & 2 & $3.99 \mathrm{bA}$ & $2.33 \mathrm{aC}$ & $2.79 \mathrm{aB}$ & $2.76 \mathrm{abB}$ & \\
\hline & 3 & $3.88 \mathrm{bcA}$ & $2.21 \mathrm{abC}$ & $2.68 \mathrm{abB}$ & $2.65 \mathrm{bcB}$ & \\
\hline & 4 & $3.76 \mathrm{cA}$ & $2.09 \mathrm{bC}$ & $2.53 \mathrm{bB}$ & $2.50 \mathrm{cB}$ & \\
\hline
\end{tabular}

Table 1: Mean values of soil total $\mathrm{N}\left(\mathrm{g} \mathrm{kg}^{-1}\right)$ in response to the interaction between irrigation levels and cover plants.

Time 1, 2, 3 and 6: sampling before cover plants deposition and at 7, 22 and 70 days after deposition, respectively. Irrigation Levels 1, 2, 3 and 4: 50, 75, 100 and 125\% of the crop evapotranspiration. PP: Cover plant Pueraria phaseoloides Benth., CM: Cover plant Calopogonium muconoides Desv., VS: Cover plant with spontaneous vegetation and BR: Banana residues. Means followed by the same letters, lowercase in columns and uppercase in rows, do not differ statistically at $5 \%$ of probability, according to $\mathrm{F}$ and Tukey tests. ${ }^{*},{ }^{* *}$ statistically significant, at $\mathrm{p}$ level $<0.05$ and $<0.01$, respectively.

In the subplots with Pueraria phaseoloides Benth high mean values of total $\mathrm{N}$ were found for all irrigation levels and evaluation times. Many factors influence decomposition rate of plant residues, being their composition the main one. Depending on the interaction between climatic factors, macro and microbiological activities of the soil, quality and quantity of plant residue, a decomposition and availability of nutrients can be fast and intense or slow and gradual [20].

The spontaneous vegetation in the experimental area was composed mainly of grasses (Panicum maximum Jacq.), which have distinct composition when compared with 
leguminous, changing its decomposition rate. When grasses are used as cover plants, they provide high production of phytomass with high carbon (C) / nitrogen (N) ratio which decrease their rates of decomposition and release of nutrients [21]. In this study this is evidenced when comparing the total $\mathrm{N}$ levels in the subplots under spontaneous vegetation and under the Pueraria phaseoloides Benth leguminous. Throughout the experiment was observed that the subplots under spontaneous vegetation had lower levels of total $\mathrm{N}$ than the subplots under Pueraria phaseoloides Benth (Table 1 ). This may be a consequence of the higher $\mathrm{C} / \mathrm{N}$ ratio that results in a slower decomposition of spontaneous vegetation and its composition. Espíndola [22] observed a C/N ratio of 79.3 for spontaneous vegetation also composed of Panicum maximum Jacq., and 23.5 for Pueraria phaseoloides Benth leguminous. About the composition, the authors observed a higher $\mathrm{N}$ content in the Pueraria phaseoloides Benth legume in relation to spontaneous vegetation and higher levels of cellulose and hemicellulose in spontaneous vegetation. Leguminous plants have higher amounts of phosphorus, potassium and calcium and lower $\mathrm{C} / \mathrm{N}$ ratio than grasses, resulting in slower decomposition of grasses in comparison with leguminous [23].

Comparing the levels of total $\mathrm{N}$ in the subplots with the legume Pueraria phaseoloides Benth and in the subplots with banana plant residues (control) it was observed that the areas under banana plant residues resulted in lower amounts of total $\mathrm{N}$ throughout the experiment. Under the same climate and soil conditions the speed of decomposition of the residues and the release of $\mathrm{N}$ are influenced by chemical characteristics especially the $\mathrm{N}$ content and $\mathrm{C} / \mathrm{N}$ ratio [16]. Banana plant residues also have higher $\mathrm{C} / \mathrm{N}$ ratio in comparison with Pueraria phaseoloides Benth residues, showing slow decomposition and nutrient liberation. Additionally to $\mathrm{C} / \mathrm{N}$ ratio, plant residues decomposition is influenced also by contents of cellulose, hemicellulose, lignin and polyphenol, as well as by the lignin / N, polyphenol / N and lignin + polyphenol / $\mathrm{N}$ ratios [24].

The subplots with Calopogonium muconoides Desv. showed low levels of total $\mathrm{N}$ throughout the experiment when compared with the subplots under Pueraria phaseoloides Benth, although both species are leguminous. The low content of total $\mathrm{N}$ found in the subplots with the leguminous Calopogonium muconoides Desv. can be explained by the small input of biomass by that cover plant, because this leguminous was sensitive to cuts, showing reduced development. The highest total $\mathrm{N}$ content of soil found in subplots with Pueraria phaseoloides Benth is explained by the fact that this specific leguminous has higher $\mathrm{N}$ fixation capacity in its tissue when compared with other leguminous plants [25].

Analyzing the isolated effect of irrigation on total $\mathrm{N}$ content, it is possible to verify the influence of irrigation after the deposition of the cover plants residues on the soil (Table 2).

\begin{tabular}{|c|c|c|c|c|c|c|}
\hline \multirow{2}{*}{ Irrigation Levels } & \multicolumn{6}{|c|}{ Time } \\
\hline & T1 & T2 & T3 & T4 & T5 & T6 \\
\hline & \multicolumn{6}{|c|}{ - } \\
\hline 1 & $1.0 \mathrm{a}$ & $1.4 \mathrm{a}$ & $2.4 \mathrm{a}$ & $3.9 \mathrm{a}$ & $3.7 \mathrm{a}$ & $3.1 \mathrm{a}$ \\
\hline 2 & $1.0 \mathrm{a}$ & $1.4 \mathrm{a}$ & $2.4 \mathrm{a}$ & $3.9 \mathrm{a}$ & $3.7 \mathrm{a}$ & $3.0 \mathrm{~b}$ \\
\hline 3 & $1.0 \mathrm{a}$ & $1.4 \mathrm{a}$ & $2.4 \mathrm{a}$ & $3.8 \mathrm{~b}$ & $3.6 \mathrm{~b}$ & $2.9 \mathrm{c}$ \\
\hline 4 & $1.0 \mathrm{a}$ & $1.4 \mathrm{a}$ & $2.3 \mathrm{a}$ & $3.8 \mathrm{~b}$ & $3.5 \mathrm{~b}$ & $2.7 \mathrm{~d}$ \\
\hline \multirow[t]{3}{*}{ F value } & $0.5725 \mathrm{~ns}$ & $0.8835 \mathrm{~ns}$ & $1.3091 \mathrm{~ns}$ & $19.3032 * *$ & $17.3908^{* *}$ & $65.7599 * *$ \\
\hline & \multicolumn{6}{|c|}{ Time } \\
\hline & $\mathrm{T} 1$ & $\mathrm{~T} 2$ & T3 & $\mathrm{T} 4$ & $\mathrm{~T} 5$ & T6 \\
\hline Soil depth & \multicolumn{6}{|c|}{-------------------------------g kg } \\
\hline 1 & $1.3 \mathrm{a}$ & $1.7 \mathrm{a}$ & $2.8 \mathrm{a}$ & $4.3 \mathrm{a}$ & $3.9 \mathrm{a}$ & $3.2 \mathrm{a}$ \\
\hline 2 & $0.6 \mathrm{~b}$ & $1.0 \mathrm{~b}$ & $1.8 \mathrm{~b}$ & $3.4 \mathrm{~b}$ & $3.3 \mathrm{~b}$ & $2.6 \mathrm{~b}$ \\
\hline $\mathrm{F}$ value & $2478.0441^{* *}$ & $1090.7216^{* *}$ & $1935.0187^{* *}$ & $2613.1232^{* *}$ & $1876.5957^{* *}$ & $2325.6438^{* *}$ \\
\hline
\end{tabular}

Table 2: Mean values of soil total $\mathrm{N}\left(\mathrm{g} \mathrm{kg}^{-1}\right.$ ) at different sampling times in response to irrigation levels and soil depths. Irrigation levels 1, 2, 3 and 4: 50, 75, 100 and $125 \%$ of the crop evapotranspiration. Time 1, 2, 3, 4, 5 and 6: sampling before cover plants deposition and at 7,22, 37, 56 and 70 days after the deposition, respectively. Soil depths 1 and 2 correspond to samples collected at 0-5 and 5-10 cm, respectively. Means followed by the same letters in columns do not differ statically at $5 \%$ of probability, according to $\mathrm{F}$ and Tukey tests. ${ }^{\mathrm{ns}}$ non-significant; ${ }^{* *}$ statistically significant, at $\mathrm{p}$ level $<0.01$. 
The irrigation effects were observed 37 days after the deposition of the cover plants. Plots with low irrigation levels showed high contents of total $\mathrm{N}$ in the soil, this result corroborates with Reichmann [12], and they observed that soil inorganic $\mathrm{N}$ pools were lower with increased water availability compared to drought conditions. The authors still declare that the availability of inorganic $\mathrm{N}$ was inversely proportional to precipitation. The increased availability of water can increase denitrification rates, creating anoxic conditions that stimulate the transformation of $\mathrm{NO}_{3}^{-}$into $\mathrm{N}_{2}$ and $\mathrm{N}_{2} \mathrm{O}$ [12]. The highest mean of the total $\mathrm{N}$ in the soil were found at depth $1(0-5 \mathrm{~cm})$. Interaction between cover plants and soil layers was observed in all sampling periods (Table 3). In all situations the leguminous Pueraria phaseoloides Benth resulted in high content of total $\mathrm{N}$ in the soil.

\begin{tabular}{|c|c|c|c|c|}
\hline \multirow{2}{*}{ Time } & \multirow{2}{*}{ Cover plants } & \multicolumn{2}{|c|}{ Soil depths } & \multirow{2}{*}{ F value } \\
\hline & & 1 & 2 & \\
\hline & & \multicolumn{2}{|c|}{ 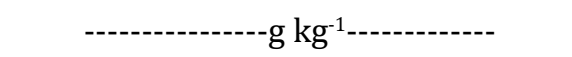 } & \\
\hline \multirow{4}{*}{1} & $\mathrm{PP}$ & $1.71 \mathrm{aA}$ & $0.93 \mathrm{aB}$ & \multirow{4}{*}{$32.1324^{* *}$} \\
\hline & CM & $1.06 \mathrm{cA}$ & $0.51 \mathrm{cB}$ & \\
\hline & VS & $1.57 \mathrm{bA}$ & $0.62 \mathrm{bB}$ & \\
\hline & $\mathrm{BR}$ & $1.05 \mathrm{cA}$ & $0.37 \mathrm{~dB}$ & \\
\hline \multirow{4}{*}{2} & $\mathrm{PP}$ & $2.74 \mathrm{aA}$ & $1.82 \mathrm{aB}$ & \multirow{4}{*}{$9.6082 * *$} \\
\hline & $\mathrm{CM}$ & $1.46 \mathrm{bA}$ & $0.81 \mathrm{bB}$ & \\
\hline & VS & $1.43 \mathrm{bcA}$ & $0.76 \mathrm{bB}$ & \\
\hline & $\mathrm{BR}$ & $1.33 \mathrm{cA}$ & $0.71 \mathrm{bB}$ & \\
\hline \multirow{4}{*}{3} & $\mathrm{PP}$ & $3.63 \mathrm{aA}$ & $2.36 \mathrm{aB}$ & \multirow{4}{*}{$25.6147^{* *}$} \\
\hline & CM & $2.74 \mathrm{bA}$ & $1.69 \mathrm{bB}$ & \\
\hline & VS & $2.78 \mathrm{bA}$ & $1.78 \mathrm{bB}$ & \\
\hline & $\mathrm{BR}$ & $2.27 \mathrm{cA}$ & $1.56 \mathrm{cB}$ & \\
\hline \multirow{4}{*}{4} & $\mathrm{PP}$ & $6.29 \mathrm{aA}$ & $5.31 \mathrm{aB}$ & \multirow{4}{*}{35.4575 ** } \\
\hline & $\mathrm{CM}$ & $4.10 \mathrm{bA}$ & $3.12 \mathrm{bB}$ & \\
\hline & VS & $3.68 \mathrm{cA}$ & $2.80 \mathrm{cB}$ & \\
\hline & $\mathrm{BR}$ & $2.97 \mathrm{dA}$ & $2.41 \mathrm{~dB}$ & \\
\hline \multirow{4}{*}{5} & $\mathrm{PP}$ & $5.42 \mathrm{aA}$ & $4.69 \mathrm{aB}$ & \multirow{4}{*}{$3.6028 *$} \\
\hline & $\mathrm{CM}$ & $3.23 \mathrm{dA}$ & $2.64 \mathrm{~dB}$ & \\
\hline & VS & $3.74 \mathrm{bA}$ & $3.08 \mathrm{bB}$ & \\
\hline & BR & $3.46 \mathrm{cA}$ & $2.82 \mathrm{cB}$ & \\
\hline \multirow{4}{*}{6} & $\mathrm{PP}$ & $4.34 \mathrm{aA}$ & $3.64 \mathrm{aB}$ & \multirow{4}{*}{$9.8326^{* *}$} \\
\hline & $\mathrm{CM}$ & $2.63 \mathrm{cA}$ & $1.86 \mathrm{cB}$ & \\
\hline & VS & $3.00 \mathrm{bA}$ & $2.37 \mathrm{bB}$ & \\
\hline & $\mathrm{BR}$ & $2.97 \mathrm{bA}$ & $2.41 \mathrm{bB}$ & \\
\hline
\end{tabular}

Table 3: Mean values of soil total $\mathrm{N}\left(\mathrm{g} \mathrm{kg}^{-1}\right)$ in response to the interaction between cover plants and soil depths

Time 1, 2, 3, 4, 5 and 6: sampling before cover plants deposition and at 7, 22, 37, 56 and 70 days after the deposition, respectively. PP: Cover plant Pueraria phaseoloides Benth., CM: Cover plant Calopogonium muconoides Desv., VS: Cover plant with spontaneous vegetation and BR: Banana residues. Soil depths 1 and 2 correspond to samples collected at 0-5 and 5-10 cm, respectively. Means followed by the same letters, lowercase in columns and uppercase in rows, do not differ statistically at $5 \%$ of probabiblity, according to $\mathrm{F}$ and Tukey tests. * ** statistically significant, at $\mathrm{p}$ level $<0.05$ and $<0.01$, respectively. 
The high content of total $\mathrm{N}$ in the first soil layer $(0-5 \mathrm{~cm})$ is a consequence of cover plants management because plant residues were not incorporated into the soil. Additionally the superficial soil layer has better conditions of temperature, humidity and oxygen for microbial activity and high contents of total N [26].

The highest total $\mathrm{N}$ content in the soil presented in the subplots with the leguminous Pueraria phaseoloides Benth in the interaction between cover plants and soil layers throughout the entire sampling period and in all situations is a consequence of the higher biomass produced by this species in comparison with the leguminous Calopogonium muconoides Desv. and spontaneous vegetation. The biomass production rate by the Pueraria phaseoloides Benth leguminous was $11.1 \mathrm{~g} \mathrm{~m}^{-2}$ while for spontaneous vegetation it was $7.7 \mathrm{~g} \mathrm{~m}^{-2}$ and Calopogonium muconoides Desv. 3.0 $\mathrm{g} \mathrm{m}^{-2}$. As well as result of the higher decomposition rate of Pueraria phaseoloides Benth in comparison to the banana plant residues.

\section{Inorganic Nitrogen}

Analyzing irrigation levels effects on the inorganic $\mathrm{N}$ forms in the soil (Table 4), was observed that high irrigation levels probably changed the nitrification dynamics that was difficulty by the higher level of irrigation, resulting in less accumulation of $\mathrm{N}-\mathrm{NO}_{3}$.

\begin{tabular}{|c|c|c|c|c|c|c|}
\hline \multirow{2}{*}{ Time } & \multirow{2}{*}{$\mathrm{N}$ forms } & \multicolumn{4}{|c|}{ Irrigation levels } & \multirow{2}{*}{ F value } \\
\hline & & L1 & L2 & L3 & $\mathrm{L} 4$ & \\
\hline & & \multicolumn{4}{|c|}{ - } & \\
\hline \multirow{2}{*}{$\mathrm{T} 1$} & $\mathrm{NO}_{3}^{-}$ & $8.63 \mathrm{a}$ & $6.89 \mathrm{ab}$ & $5.12 \mathrm{bc}$ & $3.90 \mathrm{c}$ & $18.2418^{* *}$ \\
\hline & $\mathrm{NH}_{4}^{+}$ & $5.45 \mathrm{~d}$ & $7.00 \mathrm{c}$ & $8.57 \mathrm{~b}$ & $10.19 \mathrm{a}$ & $748.1049 * *$ \\
\hline \multirow{2}{*}{$\mathrm{T} 2$} & $\mathrm{NO}_{3}^{-}$ & $11.01 \mathrm{a}$ & $9.97 \mathrm{ab}$ & $7.52 \mathrm{bc}$ & $5.91 \mathrm{c}$ & $14.7247^{* *}$ \\
\hline & $\mathrm{NH}_{4}^{+}$ & $6.09 \mathrm{~d}$ & $7.81 \mathrm{c}$ & $9.34 \mathrm{~b}$ & $11.41 \mathrm{a}$ & $4407.0449 * *$ \\
\hline \multirow{2}{*}{$\mathrm{T} 3$} & $\mathrm{NO}_{3}^{-}$ & $16.63 \mathrm{a}$ & $15.19 \mathrm{~b}$ & $13.19 \mathrm{c}$ & $11.16 \mathrm{~d}$ & $671.9400^{* *}$ \\
\hline & $\mathrm{NH}_{4}^{+}$ & $9.98 \mathrm{~d}$ & $11.90 \mathrm{c}$ & $13.95 \mathrm{~b}$ & $15.85 \mathrm{a}$ & 3815.4578 ** \\
\hline \multirow{2}{*}{$\mathrm{T} 4$} & $\mathrm{NO}_{3}^{-}$ & $26.75 \mathrm{a}$ & $24.54 \mathrm{~b}$ & $22.68 \mathrm{c}$ & $20.53 \mathrm{~d}$ & $562.9147^{* *}$ \\
\hline & $\mathrm{NH}_{4}^{+}$ & $17.36 \mathrm{~d}$ & $19.57 \mathrm{c}$ & $21.70 \mathrm{~b}$ & $23.92 \mathrm{a}$ & $7256.9463 * *$ \\
\hline \multirow{2}{*}{$\mathrm{T} 5$} & $\mathrm{NO}_{3}^{-}$ & $25.38 \mathrm{a}$ & $23.15 \mathrm{~b}$ & $20.87 \mathrm{c}$ & $18.68 \mathrm{~d}$ & $404.6841^{* *}$ \\
\hline & $\mathrm{NH}_{4}^{+}$ & $16.80 \mathrm{~d}$ & $18.60 \mathrm{c}$ & $20.49 \mathrm{~b}$ & $22.74 \mathrm{a}$ & $13829.4583^{* *}$ \\
\hline \multirow{2}{*}{$\mathrm{T} 6$} & $\mathrm{NO}_{3}^{-}$ & $23.07 \mathrm{a}$ & $20.55 \mathrm{~b}$ & $18.21 \mathrm{c}$ & $15.98 \mathrm{~d}$ & $1939.2259^{* *}$ \\
\hline & $\mathrm{NH}_{4}^{+}$ & $14.70 \mathrm{~d}$ & $16.98 \mathrm{c}$ & $18.78 \mathrm{~b}$ & $21.44 \mathrm{a}$ & $4627.0752 * *$ \\
\hline
\end{tabular}

Table 4: Mean contents of $\mathrm{N}-\mathrm{NO}_{3}{ }^{-}$and $\mathrm{N}-\mathrm{NH}_{4}{ }^{+}\left(\mathrm{mg} \mathrm{kg}^{-1}\right)$ in soil collected at six evaluation times and subjected to four irrigation levels.

Irrigation levels 1, 2, 3 and 4: 50, 75, 100 and $125 \%$ of the crop evapotranspiration. Time 1, 2, 3, 4, 5 and 6: sampling before cover plants deposition and at 7,22, 37, 56 and 70 days after the deposition, respectively. Soil depths 1 and 2 correspond to samples collected at 0-5 and 5-10 cm, respectively. Means followed by the same letters in rows do not differ statistically at 5\% of probability, according to $\mathrm{F}$ and Tukey tests. ${ }^{* *}$ statistically significant, at p level of $1 \%$.

The higher levels of irrigation may have generated an anaerobic condition making the action of nitrifying bacteria responsible for $\mathrm{NO}_{3}^{-}$production difficult. For Reichmann [12] the increase in water availability promoted by irrigation reduces oxygen availability in the soil, reducing also $\mathrm{N}-\mathrm{NO}_{3}^{-}$ whose presence is related to aerobic conditions. Paul [27] said that the water content directly affects the diffusion of different forms of inorganic N. Some studies have shown that

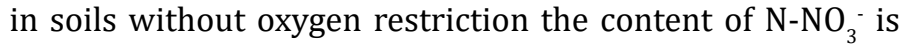
high, since nitrification is favored under aerobic conditions $[12,13]$.

Evaluating cover plants effects on inorganic $\mathrm{N}$ forms in the soil, the leguminous Pueraria phaseoloides Benth resulted in high contents of $\mathrm{N}-\mathrm{NO}_{3}{ }^{-}$and $\mathrm{N}-\mathrm{NH}_{4}{ }^{+}$throughout the study (Table 5). 
Journal of Ecology and Natural Resources

\begin{tabular}{|c|c|c|c|c|c|c|}
\hline \multirow{2}{*}{ Time } & \multirow{2}{*}{$\mathbf{N}$ forms } & \multicolumn{4}{|c|}{ Cover plant } & \multirow[t]{2}{*}{ F value } \\
\hline & & PP & CM & VS & BR & \\
\hline & & \multicolumn{4}{|c|}{---------------- mg kg-1 ------------- } & \\
\hline \multirow{2}{*}{$\mathrm{T} 1$} & $\mathrm{NO}_{3}^{-}$ & $8.51 \mathrm{a}$ & $4.93 \mathrm{c}$ & $6.21 \mathrm{~b}$ & $4.89 \mathrm{c}$ & 153.0359 ** \\
\hline & $\mathrm{NH}_{4}^{+}$ & $11.77 \mathrm{a}$ & $8.21 \mathrm{~b}$ & $6.24 \mathrm{c}$ & $4.99 \mathrm{~d}$ & $2.5980 *$ \\
\hline \multirow{2}{*}{$\mathrm{T} 2$} & $\mathrm{NO}_{3}^{-}$ & $15.08 \mathrm{a}$ & $7.23 \mathrm{~b}$ & $6.57 \mathrm{c}$ & $5.54 \mathrm{~d}$ & $976.1498^{* *}$ \\
\hline & $\mathrm{NH}_{4}^{+}$ & $12.19 \mathrm{a}$ & $9.57 \mathrm{~b}$ & $7.10 \mathrm{c}$ & $5.80 \mathrm{~d}$ & $5761.0082 * *$ \\
\hline \multirow{2}{*}{$\mathrm{T} 3$} & $\mathrm{NO}_{3}^{-}$ & $22.31 \mathrm{a}$ & $13.56 \mathrm{~b}$ & $11.08 \mathrm{c}$ & $9.22 \mathrm{~d}$ & $1835.4617^{* *}$ \\
\hline & $\mathrm{NH}_{4}^{+}$ & $17.75 \mathrm{a}$ & $14.02 \mathrm{~b}$ & $11.14 \mathrm{c}$ & $8.77 \mathrm{~d}$ & $9827.5204^{* *}$ \\
\hline \multirow{2}{*}{$\mathrm{T} 4$} & $\mathrm{NO}_{3}^{-}$ & 36.18 a & $24.51 \mathrm{~b}$ & $18.44 \mathrm{c}$ & $15.38 \mathrm{~d}$ & 3887.0299 ** \\
\hline & $\mathrm{NH}_{4}^{+}$ & $29.35 \mathrm{a}$ & $23.59 \mathrm{~b}$ & $16.06 \mathrm{c}$ & $13.54 \mathrm{~d}$ & $36713.9638^{* *}$ \\
\hline \multirow{2}{*}{$\mathrm{T} 5$} & $\mathrm{NO}_{3}^{-}$ & $30.78 \mathrm{a}$ & $14.00 \mathrm{~d}$ & $25.05 \mathrm{~b}$ & $18.25 \mathrm{c}$ & $1850.5052^{* *}$ \\
\hline & $\mathrm{NH}_{4}^{+}$ & $25.91 \mathrm{a}$ & $14.28 \mathrm{~d}$ & $20.93 \mathrm{~b}$ & $17.50 \mathrm{c}$ & 23709.8494 ** \\
\hline \multirow{2}{*}{ T6 } & $\mathrm{NO}_{3}^{-}$ & $26.78 \mathrm{a}$ & $11.53 \mathrm{~d}$ & $21.88 \mathrm{~b}$ & $17.61 \mathrm{c}$ & $807.7282 * *$ \\
\hline & $\mathrm{NH}_{4}^{+}$ & $23.47 \mathrm{a}$ & $13.27 \mathrm{~d}$ & $19.28 \mathrm{~b}$ & $15.88 \mathrm{c}$ & $20059.4148^{* *}$ \\
\hline
\end{tabular}

Table 5: Mean contents of $\mathrm{N}-\mathrm{NO}_{3}{ }^{-}$and $\mathrm{N}-\mathrm{NH}_{4}{ }^{+}\left(\mathrm{g} \mathrm{kg}^{-1}\right)$ at six evaluation times in response to cover plants.

PP: Cover plant Pueraria phaseoloides Benth., CM: Cover plant Calopogonium muconoides Desv., VS: Spontaneous vegetation, BR: banana residues. T1, T2, T3, T4, T5 and T6: sampling before cover plant deposition and at 7, 22, 37, 56 and 70 days after the deposition, respectively. Means followed by the same letters in columns do not differ statistically at $5 \%$ of probability, according to Tukey tests. ${ }^{*}{ }^{* *}$ statistically significant, at $\mathrm{p}$ level $<0.05$ and $<0.01$, respectively.

The high levels of $\mathrm{N}-\mathrm{NO}_{3}{ }^{-}$and $\mathrm{NH}_{4}{ }^{+}$in the plots with the leguminous Pueraria phaseoloides Benth may be a consequence of the high biomass input promoted by this species, as previously presented. Interaction was found

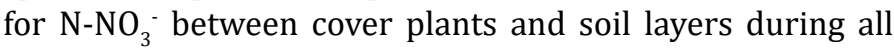

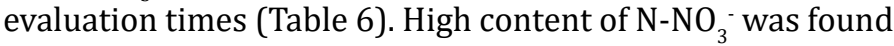
in the superficial layer, mainly in the treatment with Pueraria phaseoloides Benth with decrease in this form as soil depth increases.
The high content of $\mathrm{N}^{-} \mathrm{NO}_{3}^{-}$in the superficial layer mainly in the treatment with Pueraria phaseoloides Benth is explained by the better nitrification condition found in the superficial layer, mainly due to high aeration, once it is in contact with the atmospheric air. The high content of $\mathrm{N}^{-\mathrm{NO}_{3}}$. in the superficial layer of soils was found in other studies $[28,29]$.

\begin{tabular}{|c|c|c|c|c|}
\hline \multirow{2}{*}{ Time } & \multirow{2}{*}{ Cover plants } & \multicolumn{2}{|c|}{ Soil depths } & \multirow{2}{*}{ F values } \\
\hline & & 1 & 2 & \\
\hline & & \multicolumn{2}{|c|}{---------mg Kg ${ }^{-1}$-------- } & \\
\hline \multirow{4}{*}{1} & PP & $10.48 \mathrm{aA}$ & $6.54 \mathrm{aB}$ & \multirow{4}{*}{$36.0653 * *$} \\
\hline & $\mathrm{CM}$ & $5.54 \mathrm{cA}$ & $4.33 \mathrm{cB}$ & \\
\hline & VS & $7.08 \mathrm{bA}$ & $5.34 \mathrm{bB}$ & \\
\hline & $\mathrm{BR}$ & $5.51 \mathrm{cA}$ & $4.27 \mathrm{cB}$ & \\
\hline \multirow{4}{*}{2} & PP & $20.86 \mathrm{aA}$ & $9.29 \mathrm{aB}$ & \multirow{4}{*}{322.2213 ** } \\
\hline & $\mathrm{CM}$ & $8.33 \mathrm{bA}$ & $6.13 \mathrm{bB}$ & \\
\hline & VS & $8.31 \mathrm{bA}$ & $4.82 \mathrm{cB}$ & \\
\hline & $\mathrm{BR}$ & $6.42 \mathrm{cA}$ & $4.67 \mathrm{cB}$ & \\
\hline
\end{tabular}




\begin{tabular}{|c|c|c|c|c|}
\hline \multirow{4}{*}{3} & PP & $28.14 \mathrm{aA}$ & $16.48 \mathrm{aB}$ & \multirow{4}{*}{$338.1026^{* *}$} \\
\hline & $\mathrm{CM}$ & $16.03 \mathrm{bA}$ & $11.09 \mathrm{bB}$ & \\
\hline & VS & $13.43 \mathrm{cA}$ & $8.73 \mathrm{cB}$ & \\
\hline & $\mathrm{BR}$ & $11.96 \mathrm{dA}$ & $6.48 \mathrm{~dB}$ & \\
\hline \multirow{4}{*}{4} & PP & $42.00 \mathrm{aA}$ & $30.36 \mathrm{aB}$ & \multirow{4}{*}{234.9339 * } \\
\hline & $\mathrm{CM}$ & $26.34 \mathrm{bA}$ & $22.67 \mathrm{bB}$ & \\
\hline & VS & $20.79 \mathrm{cA}$ & $16.09 \mathrm{cB}$ & \\
\hline & $\mathrm{BR}$ & $17.09 \mathrm{dA}$ & $13.67 \mathrm{~dB}$ & \\
\hline \multirow{4}{*}{5} & PP & $35.66 \mathrm{aA}$ & $25.89 \mathrm{aB}$ & \multirow{4}{*}{111.8785 * } \\
\hline & $\mathrm{CM}$ & $16.33 \mathrm{dA}$ & $11.67 \mathrm{~dB}$ & \\
\hline & VS & $28.00 \mathrm{bA}$ & $22.09 \mathrm{bB}$ & \\
\hline & $\mathrm{BR}$ & $20.53 \mathrm{cA}$ & $15.97 \mathrm{cB}$ & \\
\hline \multirow{4}{*}{6} & PP & $28.89 \mathrm{aA}$ & $24.66 \mathrm{aB}$ & \multirow{4}{*}{$5.1668 * *$} \\
\hline & $\mathrm{CM}$ & $13.19 \mathrm{dA}$ & $9.88 \mathrm{~dB}$ & \\
\hline & VS & $23.08 \mathrm{bA}$ & $20.69 \mathrm{bB}$ & \\
\hline & $\mathrm{BR}$ & $19.04 \mathrm{cA}$ & $16.19 \mathrm{cB}$ & \\
\hline
\end{tabular}

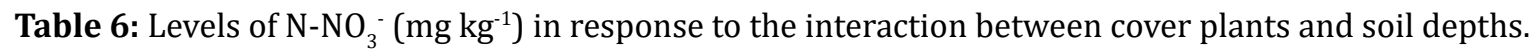

Time 1, 2, 3, 4, 5 and 6: sampling before cover plants deposition and at 7, 22, 37, 56 and 70 days after the deposition, respectively. PP: Cover plant Pueraria phaseoloides Benth., CM: Cover plant Calopogonium muconoides Desv., VS: Cover plant with spontaneous vegetation and BR: Banana residues. Soil depths 1 and 2 correspond to samples collected at 0-5 and 5-10 cm, respectively. Means followed by the same letters, lowercase in columns and uppercase in rows, do not differ statistically at $1 \%$ of probability, according to $\mathrm{F}$ and Tukey tests. ${ }^{* *}$ statistically significant, at $\mathrm{p}$ level $<0.01$.

The $\mathrm{N}-\mathrm{NH}_{4}^{+}$also showed interaction between cover plants and soil layers during all evaluation times (Table 7).

\begin{tabular}{|c|c|c|c|c|}
\hline \multirow{2}{*}{ Time } & \multirow{2}{*}{ Cover plants } & \multicolumn{2}{|c|}{ Soil depths } & \multirow{2}{*}{ F values } \\
\hline & & 1 & 2 & \\
\hline & & \multicolumn{2}{|c|}{---------mg Kg-1 -------- } & \\
\hline \multirow{4}{*}{1} & PP & $10,13 \mathrm{aB}$ & $13,42 \mathrm{aA}$ & \multirow{4}{*}{$9,6943 * *$} \\
\hline & $\mathrm{CM}$ & $6,78 \mathrm{bB}$ & $9,64 \mathrm{bA}$ & \\
\hline & VS & $5,14 \mathrm{cB}$ & $7,34 \mathrm{cA}$ & \\
\hline & $\mathrm{BR}$ & $4,17 \mathrm{~dB}$ & $5,81 \mathrm{dA}$ & \\
\hline \multirow{4}{*}{2} & $\mathrm{PP}$ & $10,83 \mathrm{aB}$ & $13,55 \mathrm{aA}$ & \multirow{4}{*}{$27,6965^{* *}$} \\
\hline & $\mathrm{CM}$ & $8,44 \mathrm{bB}$ & $10,69 \mathrm{bA}$ & \\
\hline & VS & $6,00 \mathrm{cB}$ & $8,20 \mathrm{cA}$ & \\
\hline & $\mathrm{BR}$ & $4,94 \mathrm{~dB}$ & $6,66 \mathrm{dA}$ & \\
\hline \multirow{4}{*}{3} & $\mathrm{PP}$ & $15,38 \mathrm{aB}$ & $20,12 \mathrm{aA}$ & \multirow{4}{*}{306,2940 ** } \\
\hline & $\mathrm{CM}$ & $12,84 \mathrm{bB}$ & $15,20 \mathrm{bA}$ & \\
\hline & VS & $9,25 \mathrm{cB}$ & $13,04 \mathrm{cA}$ & \\
\hline & $\mathrm{BR}$ & $7,98 \mathrm{~dB}$ & $9,56 \mathrm{dA}$ & \\
\hline
\end{tabular}




\begin{tabular}{|c|c|c|c|c|}
\hline \multirow{4}{*}{4} & $\mathrm{PP}$ & $26,92 \mathrm{aB}$ & 31,79 aA & \multirow{4}{*}{$213,7998 * *$} \\
\hline & $\mathrm{CM}$ & $22,44 \mathrm{bB}$ & $24,74 \mathrm{bA}$ & \\
\hline & VS & $14,60 \mathrm{cB}$ & $17,52 \mathrm{cA}$ & \\
\hline & $\mathrm{BR}$ & $12,44 \mathrm{~dB}$ & $14,68 \mathrm{dA}$ & \\
\hline \multirow{4}{*}{5} & $\mathrm{PP}$ & $24,74 \mathrm{aB}$ & $27,08 \mathrm{aA}$ & \multirow{4}{*}{109,5261 ** } \\
\hline & $\mathrm{CM}$ & $13,04 \mathrm{~dB}$ & $15,53 \mathrm{dA}$ & \\
\hline & VS & $19,06 \mathrm{bB}$ & $22,81 \mathrm{bA}$ & \\
\hline & BR & $16,34 \mathrm{cB}$ & $18,65 \mathrm{cA}$ & \\
\hline \multirow{4}{*}{6} & $\mathrm{PP}$ & $22,29 \mathrm{aB}$ & $24,64 \mathrm{aA}$ & \multirow{4}{*}{$84,6116^{* *}$} \\
\hline & $\mathrm{CM}$ & $11,27 \mathrm{~dB}$ & $15,28 \mathrm{dA}$ & \\
\hline & VS & $17,51 \mathrm{bB}$ & $21,04 \mathrm{bA}$ & \\
\hline & $\mathrm{BR}$ & $14,05 \mathrm{cB}$ & $17,72 \mathrm{cA}$ & \\
\hline
\end{tabular}

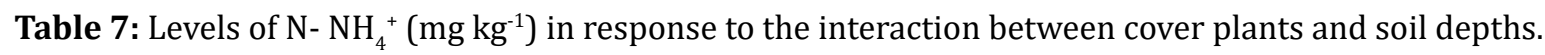

Time 1, 2, 3, 4, 5 and 6: sampling before cover plants deposition and at 7, 22, 37, 56 and 70 days after the deposition, respectively. PP: Cover plant Pueraria phaseoloides Benth., CM: Cover plant Calopogonium muconoides Desv., VS: Cover plant with spontaneous vegetation and BR: Banana residues. Soil depths 1 and 2 correspond to samples collected at 0-5 and 5-10 cm, respectively. Means followed by the same letters, lowercase in columns and uppercase in rows, do not differ statistically at $1 \%$ of probability, according to $\mathrm{F}$ and Tukey tests. ${ }^{* *}$ statistically significant, at $\mathrm{p}$ level $<0.01$.

The highest content of $\mathrm{N}-\mathrm{NH}_{4}^{+}$in the deepest layer of the soil mainly in the plots with Pueraria phaseoloides Benth it may be explained by the worse nitrification condition of the deep layer in comparison with superficial layer. The high amount of $\mathrm{N}-\mathrm{NH}_{4}{ }^{+}$in deeper soil layers was found in other studies $[30,14]$. However, it is important to highlight that high amount of $\mathrm{N}-\mathrm{NH}_{4}{ }^{+}$was found in the superficial soil layer only in association with high irrigation levels that promoted low oxygen availability for nitrification.

In general most of total $\mathrm{N}$ in this study is in organic form, probably immobilized in microbial biomass. Soil microorganisms assimilate $\mathrm{N}$ to form the organic constituents of their cells and tissues [31]. The immobilization by soil biota is an important component of the $\mathrm{N}$ potentially mineralized, once the immobilization is temporary. As microorganisms die, they are mineralized, releasing nutrients and this process will be faster as the amount of $\mathrm{N}$ in microbial biomass increases [32].

Based on the findings of the present study verified that the hypothesis formulated were proved thus being accepted for the evaluated environmental condition. From a practical point of view, in a semi-arid climate condition, the use of Pueraria phaseoloides Benth leguminous as a cover plant is indicated since it can provide higher levels of inorganic $\mathrm{N}$ for the crop of economic interest and is also more resistant to cuts ensuring good biomass production [33].

\section{Conclusion}

The use of Pueraria phaseoloides Benth as a cover plant can improve nitrogen availability for the main crop because this species promoted high input of easily decomposed biomass. High irrigation levels (100 and $125 \%$ of the crop evapotranspiration) influenced inorganic $\mathrm{N}$ forms in the soil, being $\mathrm{N}-\mathrm{NH}_{4}{ }^{+}$the most abundant. The most superficial layer of the soil showed higher content of total- $\mathrm{N}$ and most of this $\mathrm{N}$ was in the form of $\mathrm{NO}_{3}$ :

\section{Acknowledgments}

This study was financed in part by the Coordenação de Aperfeiçoamento de Pessoal de Nível Superior - Brasil (CAPES) and Northeast Bank (BNB). The authors would like to thank the staff of Vale do Curu Experimental Farm, which made field activities feasible.

\section{References}

1. Dechen AR, Nachtigall GR (2018) Elementos essenciais e benéficos às plantas. In: Fernandes MS, Sousa SR, Santos LA (Eds.), Nutrição Mineral de Plantas. $2^{\text {nd }}$ (Edn.), Sociedade Brasileira de Ciência do Solo, Viçosa, Brasil, cap. I, pp: 3-9.

2. Food and Agriculture Organization (FAO) (2015) World Fertilizer Trends And Outlook To 2018. FAO, Rome, pp: 64. 
3. Mahanta D, Bhattacharyya R, Sahoo DC, Tuti MD, Gopinath KA, et al. (2015) Optimization of Farmyard Manure to Substitute Mineral Fertilizer for Sustainable Productivity and Higher Carbon Sequestration Potential and Profitability under Gardenpea-French Bean Cropping System in the Indian Himalayas. J Plant Nutrition 38(11): 1709-1733.

4. Boithias L, Srinivasan R, Sauvage S, Macary F, SánchezPérez JM (2014) Daily nitrate losses: Implication on longterm river quality in an intensive agricultural catchment of Southwestern France. J Environ Qual 43(1): 46-54.

5. Lechenet $\mathrm{M}$, Bretagnolle $\mathrm{V}$, Bockstaller C, Boissinot $\mathrm{F}$, Petit MS, et al. (2014) Reconciling pesticide reduction with economic and environmental sustainability in arable farming. Plos One 9: 1-10.

6. Teodoro RB, Oliveira FL, Silva DMN, Fávero C, Quaresma MAL (2011) Leguminosas herbáceas perenes para utilização como coberturas permanentes de solo na Caatinga Mineira. Rev Ciênc Agron 42(2): 292-300.

7. Aynehband A, Farzad G, Fatch E (2012) Effect of different green manure crops and nitrogen levels on biomass production efficiency and nitrogen concentration in wheat (Triticum aestivum L.) and soil. Adv Environ Biol 6: 362-367.

8. Chen B, Liu E, Tian Q, Yan C, Zhang Y (2014) Soil nitrogen dynamics and crop residues. A review. Agron Sustain Dev 34: 429-442.

9. Huygens D, Díaz S, Urcelay C, Boechx P (2016) Microbial recycling of dissolved organic matter confines plant nitrogen uptake to inorganic forms in a semi-arid ecosystem. Soil Biol Biochem 101: 142-151.

10. Tian Y, Liu J, Zhang X, Gao L (2010) Effects of summer catch crop, residue management, soil temperature and water on the succeeding cucumber rhizosphere nitrogen mineralization in intensive production systems. Nutr Cycl Agroecosyst 88: 429-446.

11. Mcneill A, Unkovich M (2007) The nitrogen cycle in terrestrial ecosystems. In: Marschner P, Rengel Z (Eds.), Nutrient cycling in terrestrial ecosystems. 1st (Eds.), Springer, Berlin, Germany, 2: 37-64.

12. Reichmann LG, Sala OE, Peters DPC (2013) Water controls on nitrogen transformations and stocks in an arid ecosystem. Ecosphere 4(1): 1-17.

13. Sangoi L, Ernani PR, Lech VA, Rampazzo C (2003) Lixiviação de nitrogênio afetada pela forma de aplicação da uréia e manejo dos restos culturais de aveia em dois solos com texturas contrastantes. Ciên Rural 33(1): 6570 .

14. Maia SMF, Xavier FAS, Oliveira TS, Mendonça ES, Araújo Filho JA (2008) Frações de nitrogênio em Luvissolo sob sistemas agroflorestais e convencional no semiárido cearense. Rev Bras Ciênc Solo 32(1): 381-392.

15. Araújo HF, Costa RNT, Crisóstomo JR, Saunders LCU, Moreira OC, et al. (2012) Produtividade e análise de indicadores técnicos do maracujazeiro-amarelo irrigado em diferentes horários. R Bras Eng Agríc Ambiental 16(2): 159-164.

16. Espíndola JAA, Guerra JGM, Perin A, Teixeira MG, Almeida DL, et al. (2006) Bananeiras consorciadas com leguminosas herbáceas perenes utilizadas como coberturas vivas. Pesq Agropec Bras 41(3): 415-420.

17. Teixeira PC, Donagema GK, Fontana A, Teixeira WG (2017) Manual de métodos de análise de solo. $3^{\text {rd }}$ (Edn.), Embrapa, Brasília, pp: 573

18. Santos-Silva FA, Vieira-Azevedo CA (2002) Versão do programa computacional ASSISTAT para o sistema operacional Windows. Rev Bras Prod Agroindustriais 4(1): 71-78.

19. Ramos ME, Benítez E, García PA, Robles AB (2010) Cover crops under different managements vs. frequent tillage in almond orchards in semiarid conditions: Effects on soil quality. App Soil Ecol 44(1): 6-14.

20. Mendonça VZ, Mello LMM, Andreotti M, Pariz CM, Yano EH, et al. (2015) Liberação de nutrientes da palhada de forrageiras consorciadas com milho e sucessão com soja. Rev Bras Ciênc Solo 39(1): 183-193.

21. Borghi É, Crusciol CAC, Costa C (2006) Desenvolvimento da cultura do milho em consorciação com Brachiaria brizantha em sistema plantio direto. Energ Agricultura 21: $19-33$.

22. Espindola JAA, Guerra JGM, Almeida DL, Teixeira MG, Urquiaga S (2006) Decomposição e liberação de nutrientes acumulados em leguminosas herbáceas perenes consorciadas com bananeira. Rev Bras Ciênc Solo 30(2): 321-328.

23. Peng Q, Qi Y, Dong Y, He Y, Liu X, et al. (2014) Decomposing litter and the $\mathrm{C}$ and $\mathrm{N}$ dynamics as affected by $\mathrm{N}$ additions in a semi-arid temperate steppe, Inner Mongolia of China. J Arid Land 6: 432-444.

24. Silveira RL, Stoyanov SR, Gusarov S, Skaf MS, Kovalenko A (2013) Plant biomass recalcitrance: effect of hemicellulose composition on nanoscale forces that 
control cell wall strength. J Am Chem Soc 135(51): 19048-19051.

25. Perin A, Marinho-Guerra JG, Teixeira MG (2004) Cobertura do solo e estoque de nutrientes de duas leguminosas perenes, considerando espaçamentos e densidades de plantio. Rev Bras Ciên Solo 28(1): 207213.

26. Stone MM, Plante AF (2014) Changes in phosphatase kinetics with soil depth across a variable tropical landscape. Soil Biol Biochem 71: 61-67.

27. Paul EA (2006) Soil microbiology, ecology, and biochemistry. $3^{\text {rd }}$ (Edn.), Academic Press, Bur-lington, Massachusetts, USA, pp: 552.

28. Holst J, Brackin R, Robinson N, Lakshmanan P, Schmidt $S$ (2012) Soluble inorganic and organic nitrogen in two Australian soils under sugarcane. Agric Ecos Environ 155: 16-26.
29. Gabriel JL, Moñoz-Carpena R, Quemada M (2012) The role of cover crops in irrigated systems: Water balance, nitrate leaching and soil mineral nitrogen accumulation. Agric Ecos Environ 155: 50-61.

30. D'andréia AF, Silva MLN, Curi N, Guilherme LRG (2004) Estoque de carbono e nitrogênio e formas de nitrogênio mineral em um solo submetido a diferentes sistemas de manejo. Pesq Agropec Bras 39(2): 179-186.

31. Yevdokimov I, Gattinger A, Buegger F, Schloter M, Munch JC (2012) Changa in the structure and activity of a soil microbial community caused by inorganic nitrogen fertilization. Microbiology 81: 743-749.

32. Anderson TH (2003) Microbial eco-physiological indicators to asses soil quality. Agri Ecos Environ 98(13): 285-293.

33. Santos HG, Jacomine PKT, Anjos LHC, Oliveira VA, Oliveira JB, et al. (2006) Sistema brasileiro de classificação de solos. $2^{\text {nd }}($ Edn.), Embrapa, Rio de Janeiro, Brasil, pp: 306. 